\title{
Orthopteran communities in the conifer-broadleaved woodland zone of the Russian Far East
}

\author{
Thomas FARTMANN, Martin BEHRENS and Holger LORITZ* \\ University of Münster, Institute of Landscape Ecology, Department of Community Ecology, Robert-Koch-Str. 26, \\ D-48149 Münster, Germany; e-mail: fartmann@uni-muenster.de
}

Key words. Orthoptera, cricket, grasshopper, community ecology, disturbance, grassland, woodland zone, Lazovsky Reserve, Russian Far East, habitat heterogeneity, habitat specifity, Palaearctic

\begin{abstract}
We investigate orthopteran communities in the natural landscape of the Russian Far East and compare the habitat requirements of the species with those of the same or closely related species found in the largely agricultural landscape of central Europe. The study area is the $1,200 \mathrm{~km}^{2}$ Lazovsky State Nature Reserve (Primorsky region, southern Russian Far East) $200 \mathrm{~km}$ east of Vladivostok in the southern spurs of the Sikhote-Alin Mountains $\left(134^{\circ} \mathrm{E} / 43^{\circ} \mathrm{N}\right)$. The abundance of Orthoptera was recorded in August and September 2001 based on the number present in 20 randomly placed $1 \mathrm{~m}^{2}$ quadrates per site. For each plot (i) the number of species of Orthoptera, (ii) absolute species abundance and (iii) fifteen environmental parameters characterising habitat structure and microclimate were recorded. Canonical correspondence analysis (CCA) was used first to determine whether the Orthoptera occur in ecologically coherent groups, and second, to assess their association with habitat characteristics. In addition, the number of species and individuals in natural and semi-natural habitats were compared using a t test. A total of 899 individuals of 31 different species were captured, with numbers ranging between 2 and 13 species per plot. Species diversity was higher in semi-natural habitats than natural habitats. There was a similar but non-significant pattern in species density. Ordination analysis indicated four orthopteran communities, which were clearly separable along a moisture and vegetation density gradient. The natural sites in the woodland area of the Lazovsky Zapovednik are characterized by species-poor and low-density orthopteran assemblages compared to the semi-natural sites. But, the natural sites have a higher diversity of habitat specialists. Our findings corroborate the hypothesis that intermediate habitat disturbance levels support particularly species-rich animal communities at high densities. Under such regimes, orthopterans presumably mostly profit from the high diversity in plant species, which generates great structural and microclimatic heterogeneity.
\end{abstract}

\section{INTRODUCTION}

While natural forests in Europe were to a great extent transformed by man into agricultural land and settlement, huge areas of the East Palaearctic are still forested (Newell, 2004; Yan \& Shugart, 2005) and thus are important reference areas for the study of temperate woodland landscapes. The Far East is one of the three biodiversity hotspots in Russia (Venevsky \& Venevskaia, 2005) and a centre of diversity and endemism of Orthoptera in Eurasia (Sergeev, 1998).

Their taxonomy and distribution are well studied, and the ease with which they can be sampled and their functional importance make Orthoptera suitable subjects for ecological and biogeographical studies (Sergeev, 1997; Lockwood \& Sergeev, 2000). Habitat selection in Orthoptera is based on a complex combination of different and often interrelated environmental factors. Of these parameters, the microclimate at oviposition sites, which is often affected by vegetation structure, plays a crucial role (Uvarov, 1977; Willott \& Hassall, 1998).

Sergeev (1997) stressed the suitability of orthopteran communities for ecological and biogeographical investigations. In recent decades many such studies have been done in the northern hemisphere. Especially in North
America, where different aspects of rangeland grasshopper communities have been studied in detail (e.g. Kemp et al., 1990; Kemp, 1992a, b; Fielding \& Brusven, 1993a, b, 1995; Joern, 2004, 2005). Most community studies in the Palaearctic are for central Europe and dry and semi-dry grassland habitats (e.g. Fartmann, 1997; Behrens \& Fartmann, 2004). Information on the Asian part of the Palaearctic is restricted to biogeographic data (Stebaev et al., 1989; Sergeev, 1998) and detailed studies of orthopteran assemblages are lacking. Since woodlands are usually not considered to be an orthopteran habitat (Theuerkauf \& Rouys, 2006) and old forests are rare in central Europe, little is known about habitat selection and community structure of Orthoptera in natural woodland areas in the Palaearctic.

We therefore investigated orthopteran communities in the natural landscape of the Russian Far East and compared the results with observations from the human and agriculturally dominated landscape of central Europe, because many taxa occur throughout the Palaearctic (Sergeev, 1992, 1997). Hence, orthopteran assemblages in the Lazovsky State Nature Reserve (Primorsky region, Russian Far East) were studied to (i) determine their species composition and abundance in different natural and seminatural habitats, (ii) analyse orthopteran habitat require-

\footnotetext{
* Present address: Helmholtz-Centre for Environmental Research Leipzig-Halle UFZ, Department of Community Ecology, Theodor-Lieser-Str. 4, D-06120 Halle, Germany.
} 


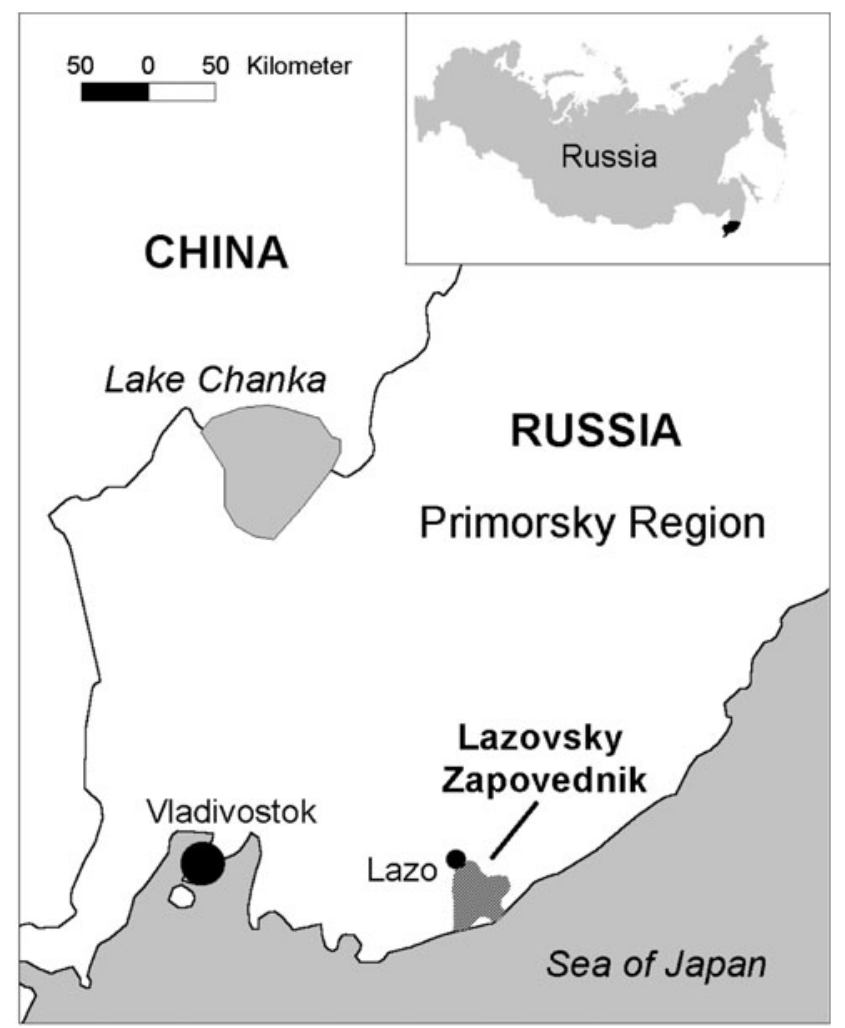

Fig. 1. Study area and location of Lazovsky Zapovednik.

ments in relation to habitat structure and microclimate and (iii) compare orthopteran habitat preferences there and in Europe where the same or closely related species occur.

\section{MATERIAL AND METHODS}

\section{Study area}

The study area is located in the Primorsky region (southern Russian Far East, Fig. 1). The landscape is formed by the Sikhote-Alin Mountains, stretching from the southwest to the northeast, parallel to the coastline (average altitude about $1,000 \mathrm{~m}$ a. s. 1.). Woodland covers $80 \%$ of the Primorsky region - taiga in the north, conifer-broadleaved woodlands in the south (Newell, 2004).

The $1,200 \mathrm{~km}^{2}$ sized Lazovsky State Nature Reserve (i.e. Lazovsky "Zapovednik", the official Russian category for this protected area) is situated about $200 \mathrm{~km}$ east of Vladivostok in the southern spurs of the Sikhote-Alin Mountains $\left(134^{\circ} \mathrm{E} / 43^{\circ} \mathrm{N}\right)$. It mainly consists of woodlands dominated by Mongolian oak (Quercus mongolica) with an admixture of Korean pine (Pinus koraiensis) and various other tree species. The species richness of the Zapovednik is impressive (1212 species of vascular plants, 57 mammals and 318 birds), with many rare and highly endangered species including the Amur tiger (Panthera tigris altaica) (Chochrjakow \& Schochrin, 2002; Newell, 2004). Open habitats are very rare, and include natural coastal dunes and swamps, parts of the floodplains, screes and mountain peaks, anthropogenic meadows in woodland-clearings near the three ranger camps and a few set-aside fields at the reserve border.

A monsoon climate with warm, humid summers and cold, dry winters is characteristic of the study area. The average annual precipitation is $750-850 \mathrm{~mm}$, decreasing from the coast inland. Due to a greater influence of continental climate the mean temperature inland is $-20^{\circ} \mathrm{C}$ in January and $20^{\circ} \mathrm{C}$ in July-August.
At the coast winters are warmer (average January temperature: $-11^{\circ} \mathrm{C}$ ) and summers cooler (average August temperature: $17^{\circ} \mathrm{C}$ ) (Semenchenko, 2003).

\section{Sampling of Orthoptera}

Sampling was carried out on 18 plots representing all the typical orthopteran habitats of the Lazovsky Zapovednik, except floodplains, which were studied by Specht (2004). Nine natural (coastal dunes, semi-dry coastal grasslands, swamps) and nine semi-natural habitats (fallows dominated by Artemisia spp. and meadows) were investigated. The area of the plots was $>2,000-10,000 \mathrm{~m}^{2}$ with a homogenous vegetation structure at every site.

Orthopteran densities were recorded in box quadrats (Gardiner et al., 2005) of a total area of $20 \mathrm{~m}^{2}$. From 29/08-15/09/2001 one sample was taken on each plot: The mobile $1 \times 1 \mathrm{~m}\left(1 \mathrm{~m}^{2}\right)$ and $80 \mathrm{~cm}$ high quadrat was randomly placed at twenty different points. Sampling was done in sunshine at temperatures $>20^{\circ} \mathrm{C}$, between 10:00 a.m. and 5:00 p.m.

Except for the small Nemobiinae species, which live hidden under stones or in litter on the ground, sampling provided reliable quantitative data. Most of the specimens were determined in the field and then released. Individuals that could not be identified in the field (Tetrix spp., some Chorthippus spp.) and voucher specimens of each species were collected and identified later. For determination the keys of Bey-Bienko \& Mishchenko (1951a, b) and Storozhenko (1986) were used. Nomenclature is based on Storozhenko (1986) and for species that also occur in Europe on Heller et al. (1998).

\section{Habitat structure}

For each plot we measured/estimated fifteen environmental parameters: inclination, exposure, heights of one (minimum) up to three different vegetation layers (e.g. turf - tall grass - Artemisia) and \% cover of the following habitat components: total vegetation, field layers, Cyperaceae, Poaceae, herbs, mosses, litter, bare soil, stones and hollows (in swamps).

\section{Data analysis}

Canonical correspondence analysis (CCA) (using CANOCO 4.51; ter Braak \& Šmilauer, 2002), a direct gradient ordination technique, was used to determine the organization of orthopteran species into distinct communities and the relations between habitat structure and species composition (Fielding \& Brusven, 1993b, 1995; Palmer, 1993; Szövényi, 2002; Torrusio et al., 2002). Environmental and species data were log arithmically transformed $\left[y^{\prime}=\ln (y+1)\right]$ to obtain approximately normal distributions and homogenous variances. Species of Orthoptera that occurred only on one plot and/or of which $<10$ specimens in total were found were not included in the data set (Table 1). Inclination and exposure were not used as variables in the CCA because only two plots were slightly inclined $\left(<5^{\circ}\right)$; cover $(\%)$ of bare soil and stones made up one variable; out of the three field layer heights the maximum vegetation height was used in CCA. The statistical validity of the ordination was tested using a Monte Carlo permutation test (null model: 9,999 unrestricted permutations). This was carried out for every environmental variable and all canonical axes (i.e. the complete model). Only significant variables were included stepwise in the model, and at each step only the variable that explained most of the remaining error variance (manual-forward selection of CANOCO) was chosen. Non-significant variables were those that explained little of the additional variance at the time they could be added to the model. They also may intercorrelate with other environmental variables (Storch et al., 2003); which was examined using Spearman's rank correlation analysis. 
TABLE 1. The 14 most common orthopteran species on the 18 plots in order of their fidelity. Species that occurred only on one plot and/or with $<10$ specimens in total are not included (see Data analysis). Distribution in Europe: species that also occur in Europe are indicated by an "+". Exlusiveness: species that are restricted to natural (n) and semi-natural (sn) habitat types are indicated.

\begin{tabular}{|c|c|c|c|c|c|c|}
\hline Species & Abbreviation & $\begin{array}{l}\text { Fidelity (no. of } \\
\text { occupied plots) }\end{array}$ & $\begin{array}{c}\text { Sum of } \\
\text { specimens }\end{array}$ & $\begin{array}{l}\text { Density } \\
\text { (ind./10 } \mathrm{m}^{2} \text { ) }\end{array}$ & $\begin{array}{l}\text { Distribution } \\
\text { Europe }\end{array}$ & $\begin{array}{l}\text { Exclusive- } \\
\text { ness }\end{array}$ \\
\hline Phaneroptera falcata (Poda, 1761) & Ph.fal & 13 & 54 & 1.50 & + & . \\
\hline Polionemobius taprobanensis (Walker, 1869) & Po.tap & 12 & 270 & 7.50 & . & . \\
\hline Tetrix japonica (Bolivar, I., 1897) & Te.jap & 9 & 23 & 0.64 & . & . \\
\hline Oecanthus longicaudus Matsumura, 1904 & Oe.lon & 8 & 45 & 1.25 & . & sn \\
\hline Ruspolia nitidula (Scopoli, 1786) & Ru.nit & 5 & 31 & 0.86 & + & $\mathrm{n}$ \\
\hline Chorthippus maritimus Mishchenko, 1951 & Ch.mar & 4 & 12 & 0.33 & + & $\mathrm{n}$ \\
\hline Chorthippus hammarstroemi (Miram, 1908) & Ch.ham & 4 & 64 & 1.78 & . & sn \\
\hline Chorthippus schmidti (Ikonnikov, 1913) & Ch.sch & 4 & 13 & 0.36 & . & . \\
\hline Omocestus haemorrhoidalis (Charpentier, 1825) & Om.hae & 4 & 23 & 0.64 & + & $\mathrm{n}$ \\
\hline $\begin{array}{l}\text { Dianemobius fascipes nigrofasciatus } \\
\text { (Matsumura, 1904) }\end{array}$ & Di.fas & 3 & 39 & 1.08 & & $\mathrm{sn}$ \\
\hline Mecostethus parapleurus (Hagenbach, 1822) & Me.par & 3 & 16 & 0.44 & + & sn \\
\hline Teleogryllus infernalis (Saussure, 1877) & Te.inf & 3 & 13 & 0.36 & . & . \\
\hline Oxya maritima Mishchenko, 1951 & Ox.mar & 2 & 36 & 1.00 & . & $\mathrm{n}$ \\
\hline Pteronemobius nitidus (Bolivar, I., 1901) & Pt.nit & 1 & 116 & 3.22 & . & $\mathrm{n}$ \\
\hline
\end{tabular}

T tests (using SPSS 11.5) were used to assess significant differences in orthopteran density and species number for the plots at the natural and semi-natural sites. Prior to the analyses, variables were tested for normal distribution using KolmogorovSmirnov test.

\section{RESULTS}

\section{Species richness and abundance}

A total of 31 species (9 Tettigoniidae, 5 Gryllidae, 1 Tetrigidae and 16 Acrididae) and a sum of 899 specimens were captured. Species number ranged from 2 to 13 per plot. Phaneroptera falcata and Polionemobius taprobanensis were the most widespread species occurring in $13(72 \%)$ and $12(67 \%)$ of the plots, respectively (Table 1). The total number of species was higher at semi-natural (mean values \pm SE: $9.11 \pm 0.75)$ than natural sites $(5.11 \pm$ 0.82 ) (t test, $\mathrm{t}=-3.582$, $\mathrm{df}=16, P=0.01)$. Similarly orthopteran density [individuals (ind.) $/ 10 \mathrm{~m}^{2}$, excluding Nemobiinae] was higher at semi-natural (mean values \pm $\mathrm{SE}: 17.44 \pm 4.21)$ than natural sites $(8.89 \pm 2.15)$. However, the difference was not significant ( $\mathrm{t}$ test, $\mathrm{t}=-1.812$, $\mathrm{df}=16, P=0.089)$. In general there was a positive relationship between species richness and overall orthopteran density $\left(\mathrm{Y}=0.735 \mathrm{x}+3.628, R^{2}=0.27, P<0.05\right)$. Of the semi-natural sites, young fallows $(N=4)$ had the highest species numbers $(9.75 \pm 1.49)$ and densities $(28.50 \pm 5.52$ ind. $\left./ 10 \mathrm{~m}^{2}\right)$. In contrast to the total number of species, that of abundant species restricted to one of the habitat types was more or less the same (Table 1). Five species occurred exclusively in natural (swamps and dunes: Chorthippus maritimus, Omocestus haemorrhoidalis, Oxya maritima, Pteronemobius nitidus and Ruspolia nitidulus) and four in semi-natural habitats (meadows and abandoned fields: Chorthippus hammarstroemi, Dianemobius fascipes nigrofasciatus, Mecostethus parapleurus and Oecanthus longicaudus).

\section{Orthopteran assemblages}

Five of the ten environmental variables significantly contributed to the CCA ordination model. The model explained $60 \%$ of the variance in the number of species and $96 \%$ of the variance in the species-environment relation (total inertia: 3.08, sum of all canonical eigenvalues: 1.93; Monte Carlo test: $F=4.04, P \leq 0.001)$. Each of the four canonical axes was highly correlated with one particular environmental variable, facilitating the ecological interpretation of each axis (see Table 2 for details). All non-significant variables intercorrelated with other environmental variables (Table 3 ) and explained $<10 \%$ additional variance at the stage when they would have been included in the model.

Based on the first two canonical axes four distinct communites can be separated (Fig. 2a): Cover of hollows strongly correlated with the first canonical axis. Note that there is no "real" environmental moisture gradient underlying this ordination pattern, because there are only two plots (swamps) with hollows. Along the first canonical axis species are divided into two distinct main groups: Taxa that were recorded only in swamps (natural habitat) and those only in mesic to dry habitats (semi-natural and natural habitats). The swamps have a species-poor orthopteran community. However, two species, Oxya maritima and Pteronemobius nitidus, were restricted to the wetlands.

Based on the arrangement of species along the second canonical axis it is possible to further discriminate between of the orthopteran communities in the remaining habitats. The axis is negatively correlated with herb cover. The strongest positive correlations (in order of arrangement) with herb cover are for Mecostethus parapleurus, Chorthippus hammarstroemi, Oecanthus longicaudus and Dianemobius fasciatus. They form a second 
TABLE 2. Summary of CCA for 14 orthopteran species $(N=$ 755 specimens) and five significant environmental variables ( $F$-values of Monte Carlo test, ${ }^{* * *} P<0.001,{ }^{*} P<0.05$ ).

\begin{tabular}{lccccc}
\hline Environmental Axis & 1 & 2 & 3 & 4 & $F$ \\
\hline Eigenvalue & 1.00 & 0.38 & 0.28 & 0.20 & \\
Species-environment correlations & 1.00 & 0.85 & 0.88 & 0.76 & \\
Variance explained (\%): & & & & & \\
$\quad$ Species data & 32.5 & 12.4 & 8.9 & 6.4 & \\
$\quad$ Species-environment relation & 51.8 & 19.7 & 14.0 & 10.5 & \\
Linear correlation with cover & & & & & \\
(\%) of: & & & & & \\
Hollows & $\mathbf{1 . 0 0}$ & 0.00 & 0.02 & $0.017 .69^{* * *}$ \\
Herbs & $-0.21-\mathbf{0 . 7 1}$ & $0.26-0.15$ & $2.10^{*}$ \\
Poaceae & -0.46 & 0.20 & $\mathbf{0 . 7 1}-0.25$ & $2.15^{*}$ \\
Field layers & $0.04-0.23$ & $0.48-\mathbf{0 . 8 3}$ & $2.19^{*}$ \\
Cyperaceae & 0.42 & 0.54 & $-0.06-0.42$ & $2.15^{*}$ \\
\hline
\end{tabular}

community found in herb-rich fallows and meadows (semi-natural habitat).

Clearly separated from all other species and strongly negatively correlated with herb cover is Chorthippus maritimus. On the most extreme dune sites (natural habitat) with sparse vegetation and short swards Chorthippus maritimus is typical of the third species-poor community. Sporadically a few other species occur at low density.

Also, but to a lower extent Omocestus haemorrhoidalis and Ruspolia nitidula are negatively correlated with herb cover. Both species occur syntopically in coastal semi-dry grasslands (natural habitat) when they form part of another orthopteran community.

Further insights in the relations between species of Orthoptera and vegetation structure are indicated by the third and fourth axes (Fig. 2b). The following species are positively correlated with the cover of field layers and Poaceae: Ruspolia nitidula, Phaneroptera falcata and Polionemobius taprobanensis. $R$. nitidula was most abundant in Poaceae-rich and dense coastal grasslands. P. falcata and $P$. taprobanensis were found in nearly all habitats, except the coastal dunes with extensive areas of bare ground and swamps.
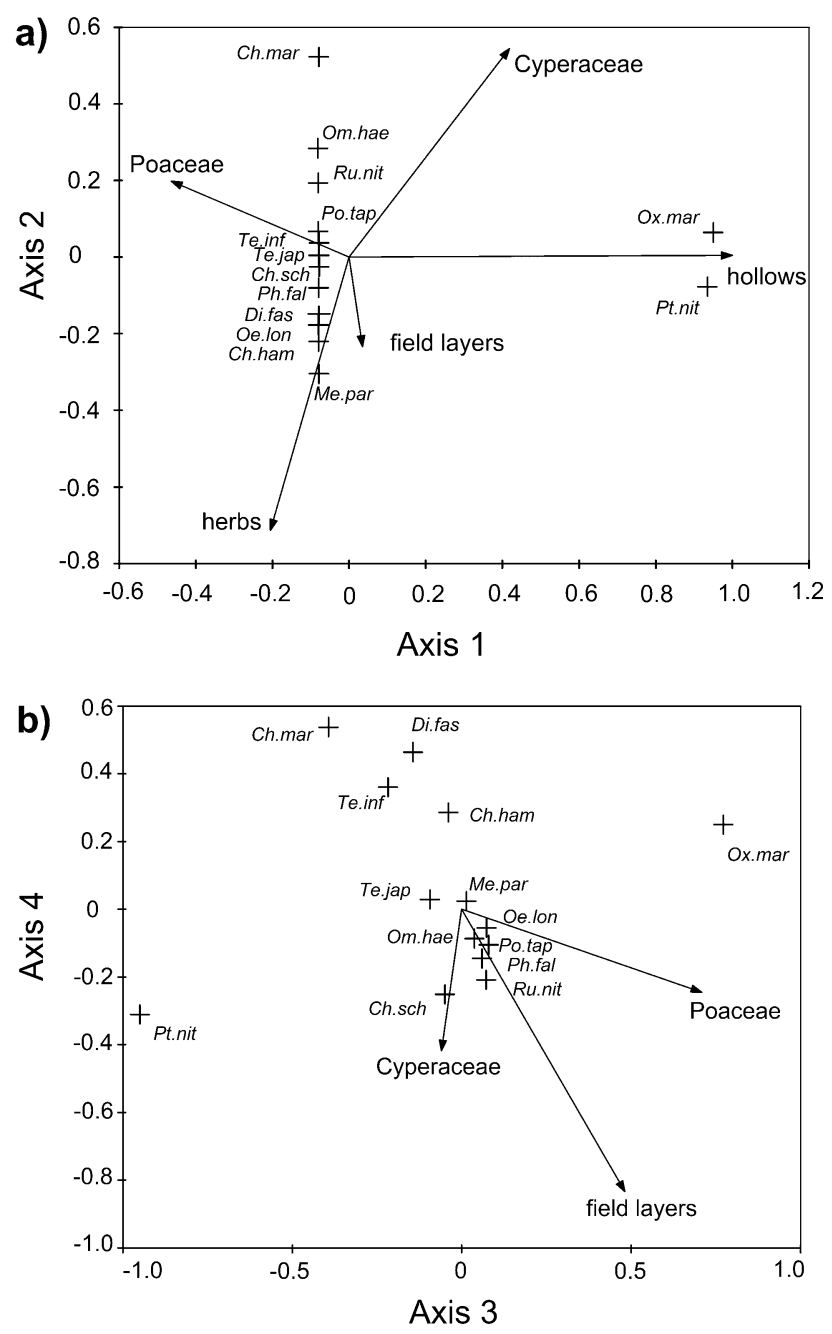

Fig. 2. Biplots for the axes of canonical correspondence analysis (CCA): a - first vs. second axis; $b$ - third vs. fourth axis. Significant environmental/ground cover variables (arrows) and position of orthopteran species (crosses). Abbreviation of species names (see Table 1). Two variables (hollows, herbs), which do not correlate with axis three and four (see Table 2), i. e. their vectors were close to zero, are not shown in $b$.

A group of four species (Chorthippus hammarstroemi, Teleogryllus infernalis, Dianemobius fascipes and Chorthippus maritimus), which are further from the origin of

TABLE 3. Correlation matrix of Spearman's rank correlation analyses $\left(N=18 ; * * * P<0.001,{ }^{* *} P<0.01,{ }^{*} P<0.05\right)$.

\begin{tabular}{|c|c|c|c|c|c|c|c|c|c|}
\hline \multirow{2}{*}{$\begin{array}{l}\text { Environmental } \\
\text { variables }\end{array}$} & \multirow[b]{2}{*}{$\begin{array}{l}\text { Vegetation } \\
\text { height }(\mathrm{cm})\end{array}$} & \multicolumn{8}{|c|}{ Ground cover $(\%)$} \\
\hline & & Hollows & $\begin{array}{c}\text { Bare soil/ } \\
\text { stones }\end{array}$ & Litter & Moss & Cyperaceae & Poaceae & Herbs & $\begin{array}{c}\text { Field } \\
\text { layers }\end{array}$ \\
\hline \multicolumn{10}{|l|}{ Ground coverage } \\
\hline Vegetation total & 0.31 & 0.39 & $-0.87 * * *$ & 0.44 & -0.18 & 0.39 & 0.37 & 0.24 & $0.83 * * *$ \\
\hline Field layers & $0.56^{*}$ & 0.11 & $-0.71 * *$ & $0.67 * *$ & -0.37 & 0.13 & $0.53^{*}$ & $0.49 *$ & \\
\hline Herbs & $0.48^{*}$ & -0.20 & -0.27 & 0.37 & -0.33 & -0.20 & -0.04 & & \\
\hline Poaceae & 0.23 & 0.01 & -0.33 & 0.37 & -0.07 & -0.27 & & & \\
\hline Cyperaceae & -0.23 & 0.39 & -0.53 & -0.03 & 0.40 & & & & \\
\hline Moss & -0.41 & $0.51 *$ & -0.23 & -0.36 & & & & & \\
\hline Litter & 0.23 & -0.12 & $-0.49^{*}$ & & & & & & \\
\hline Bare soil and stones & -0.14 & -0.45 & & & & & & & \\
\hline Hollows & 0.14 & & & & & & & & \\
\hline
\end{tabular}


the axis, is strongly negatively correlated with cover of field layers and Poaceae. C. hammarstroemi, D. fascipes and $T$. infernalis reach their highest densities in fallows with bare soil. The first two are restricted to these sites.

\section{DISCUSSION}

\section{Species richness and abundance}

According to Stebaev et al. (1989) many of the observed orthopteran species are associated with the southern border of the forest zone and limited to the Pacific Ocean districts of the Russian Far East with a monsoon climate. Numerous species are concentrated in the study area, in regions of conifer-broadleaved forest and forest-steppe in the south of the Russian Far East (Stebaev et al., 1989; Sergeev, 1992).

The natural sites in the woodland area of the Lazovsky Zapovednik are characterized by species-poor and lowdensity orthopteran assemblages compared to the seminatural sites. At the semi-natural sites the highest densities and species numbers were found on young fallows. The young set-aside fields studied were characterized by the highest structural heterogeneity.

What are the reasons for a high orthopteran diversity at the semi-natural sites? Several studies (Fartmann \& Mattes, 1997; Kruess \& Tscharntke, 2002; Gebeyehu \& Samways, 2003) indicate that orthopteran species richness is highest at sites subject to intermediate disturbance (e.g. grazing) and high structural heterogeneity. Joern (2005) found that grasshopper species richness in grassland is positively correlated with plant species richness and heterogeneity of vegetation structure, and negatively with vegetation height and grass biomass. Sites subject to an intermediate level of disturbance (like young fallows) have more plant species (Grime 1973a, b) and therefore a greater structural heterogeneity. Thus, greater resources are available for the coexistence of more orthopteran species (Dennis et al., 1998). In our view oviposition sites and food resources are the most important, especially the presence of bare ground for oviposition can be a limiting factor. Many, or even the majority of orthopteran species lay their eggs in the ground and prefer bare or sparsely covered ground for oviposition (Richards \& Waloff, 1954). In this study the number of orthopteran species exclusive to natural and semi-natural sites is similar (5 vs. 4 species). Including the orthopteran data of Specht (2004) for the floodplains of the Lazovsky Zapovednik and thus all the typical natural orthopteran habitats in the study area, five further species are restricted to natural habitats [Bryodemella tuberculata (Fabricius, 1775), Dianemobius csikii (Bolivar, I., 1901), Eirenephilus longipennis (Shiraki, 1910), Oedaleus infernalis Saussure, 1884 and Tetrix tenuicornis (Sahlberg, 1893)]. Orthopteran assemblages of the natural sites of the Lazovsky Zapovednik are species-poor, but have a greater diversity of highly specialised species.

In accordance with the results of Joern (2005) there is a positive relationship between overall Orthopteran density and species richness, indicating that there are at least some parameters that promote both species diversity and density. High orthopteran densities are often the result of a trade-off between optimal microclimatic conditions on the one hand and sufficient food and low predation pressure on the other (Fielding \& Brusven, 1992; Gottschalk, 1996; Fartmann \& Mattes, 1997; Behrens \& Fartmann, 2004). Of crucial importance for Orthoptera abundance are the microclimatic conditions during egg and larval development (Ingrisch, 1979, 1980). In this period most species benefit from high temperatures (van Wingerden et al., 1991a). In the sparse vegetation of the coastal dunes microclimate may be favourable, but food shortage and easy access for avian predators seem to result in a low orthopteran density. An increase in vegetation density results in lower temperatures in the egg habitat, mostly located near the soil surface (van Wingerden et al., 1991a). Although, the dense stands of the old set-aside fields should provide enough food and enemy-free space, the microclimate seems to be unfavourable for many orthopteran species. Because the young open Artemisia fallows in the Lazovsky Zapovednik provide the best combination of requirements, the orthopteran abundance there is the highest.

\section{Orthopteran assemblages}

Presence and assemblage of orthopteran species are distinctly different among habitat types. This depends on orthopteran habitat preference, which is determined by species adaptation to habitat structure, microclimate and disturbance intensity (Joern, 1982; Fielding \& Brusven, 1995; Samways, 1997; Szövényi, 2002). The distribution pattern of eurytopic and stenotopic species differ - due to their specific habitat requirements with the latter species characteristic of different habitat types in the Lazovsky Zapovednik. Where possible, the following compares the present results (Fig. 2, Table 1) with ecological observations from Europe.

The eurytopic and thermophilous species Phaneroptera falcata and Polionemobius taprobanensis are not restricted to one orthopteran community and occur in both natural and semi-natural habitats in the study area. However, their habitat requirements differ. The terricolous, flightless cricket $P$. tabrobanensis is found in high densities in short-turf vegetation. It is a thermophilous species distributed throughout the Indo-Malayan region and the southern Far East (Schmidt 1999). The phytophilous/arbusticolous and very mobile (capable of flying) bush-cricket $P$. falcata occurs on those habitats at low densities. It prefers tall herbaceous vegetation and has a Transpalaearctic distribution (Detzel, 1998a).

The following groups of species have a higher habitat specifity and form four distinct orthopteran communities:

\section{Community of coastal dunes with bare ground}

The geophilous Chorthippus maritimus, a far eastern sibling species of $C$. biguttulus (Linnaeus, 1758) (Krivolutskaya, 1997), occurs in the study area only in natural and dynamic habitats with extensive areas of bare ground or stones, such as coastal dunes, floodplains or screes (own observation). In the floodplains of the Lazovsky Zapovednik it typically co-occurs with Bryodemella 
tuberculata and Eirenephilus longipennis (Specht, 2004). C. biguttulus, a Eurosiberian and common species in central Europe, shows different habitat requirements: it is phytophilous and eurytopic with a preference for semi-dry grassland (Fartmann, 1997; Behrens \& Fartmann, 2004).

\section{Community of semi-dry coastal grassland}

Ruspolia nitidula, a Palaeotropic/Mediterranean species is thermophilous, phytophilous/graminicolous and especially the immature stages are hygrophilous (Detzel, 1998b). The restriction of this bush-cricket to coastal grassland with a moderate maritime climate in the Lazovsky Zapovednik seems to result from these adaptations. $R$. nitidula prefers vertical structures and in the study area it is most abundant (up to 7 individuals $/ 10 \mathrm{~m}^{2}$ ) in ecotones of dense, tall-grass stands, which possibly offer a suitable microclimate and structure.

The stenotopic Omocestus haemorrhoidalis, a Transpalaearctic species, has similar vegetation structure preferences in the Lazovsky Zapovednik and in central Europe. It is geo-/phytophilous, graminicolous, xero- and thermophilous. Microhabitat preferences in the Russian Far East correspond to those observed by Fartmann (1997) in northeast Germany: open, short-turf semi-dry grassland with structural heterogeneity and bare soil.

\section{Community of herb-rich meadows and fallows}

Mecostethus parapleurus and Oecanthus longicaudus are herbicolous and thermophilous species of the herbrich fallows and meadows in the study area. M. parapleurus is distributed along the southern boundary of the nemoral woodland zone from the Atlantic Ocean to Japan; in central Europe it is a thermophilous species, which prefers wet meadows (Detzel, 1998c). The habitat requirements of $O$. longicaudus seem to resemble those of the Mediterranean O. pellucens (Scopoli, 1763) in central Europe: According to Detzel (1998d) O. pellucens is a typical species of tall forb-rich plant communities.

Chorthippus hammarstroemi is an eastern Palaearctic, meso-xerophilous steppe species (Sergeev, 1997) that is abundant in anthropogenic habitats, such as fields (Sergeev, 1998). In the Lazovsky Zapovednik the cricket Dianemobius fascipes nigrofasciatus occurs syntopically with C. hammarstroemi exclusively in recently set-aside fields, but reaches its highest density in open, dry fallows with much bare soil/stones. Hence, this terricolous cricket is considered to be thermo- and xerophilous. On the Kuril Islands it colonises soils heated by volcanic activity, close to solfataras and fumaroles (Krivolutskaya, 1997). It is widely distributed in the temperate region of East Asia; on the Japanese Islands the southern range limit is about $30^{\circ} \mathrm{N}$ (Masaki, 1996).

\section{Community of swamps}

The hygrophilous and phytophilous/graminicolous Oxya maritima (Catantopinae) occurs together with the terricolous cricket Pteronemobius nitidus in the coastal swamps. Masaki \& Oyama (1963) describe P. nitidus as a typical species of paddy fields in North Japan. The habitat requirements seem to resemble those of the sibling spe- cies $P$. heydenii (Fischer, 1853) with a Holomediterranean origin (Kiechle, 1998) and a Mediterranean-southwest Asian distribution (Baur et al., 2006). $P$. heydenii is characterised as hygrophilous, terricolous and thermophilous; typical habitats in central Europe are south-facing lakeshores, swamps or wet meadows (Kiechle, 1998; Winterholler \& Bierwirth, 2003).

\section{CONCLUSIONS}

The majority of Orthoptera in the boreal and temperate forest zones of the Palaearctic are associated with open habitats (Sergeev, 1992, 1997). These grassland habitats often are created and maintained by disturbance (Theuerkauf \& Rouys, 2006), which is especially important at the microhabitat scale. At this level, disturbance creates the microclimatic conditions and microhabitats necessary for the survival of eggs and larval stages. This applies to Orthoptera and other thermophilous insects (e.g. Lepidoptera: Fartmann, 2004, 2006). As for the whole temperate zone of the Palaearctic (Birks, 2005; Mitchell, 2005), closed forests are the natural vegetation of most parts of the Lazovsky Zapovednik. In the absence of man, open habitats are restricted to sites with extreme environmental conditions. Only sites that are highly disturbed (dunes, floodplains), too dry (dunes, screes) or wet (swamps) and too cold (mountain tops) are free of trees, all the intermediate sites are covered with woodland. Due to the origin of the landscape one would expect that the hot spots of orthopteran diversity and density will be sites created by natural disturbance. But, this is not the case as semi-natural sites subject to anthropogenic disturbance (recently set-aside fields) have the highest species numbers and abundance. The orthopteran communities of the natural habitats are not as species-rich as the anthropogenic sites, but there are more stenotopic species restricted to those habitats.

Comparable observations exist for central Europe; but disturbance intensity as well as the spatial and temporal pattern in the cultural European landscape are very different from a natural landscape. Human activity in central Europe creates either extensive and continuously high disturbance (e.g. intensive cropland) or approximately stable conditions with low disturbance frequency (e.g. high forests with long cutting intervals), which both lead to habitat loss for insects of open habitats. Natural, dynamic disturbance patterns and low-intensity anthropogenic management have positive effects on habitats and populations of stenotopic insects (Sergeev, 1998; Di Giulio et al., 2001), but today such practices are rare in central Europe (Fartmann, 2006). Hence, our findings in the natural landscape of the Russian Far East confirm a strategy of nature conservation that has recently attracted interest in central Europe. That is, the conservation and restoration of natural landscape dynamic/disturbance (Finck et al., 1998) and support of anthropo-zoogenic management with low intensity (van Wingerden et al., 1991b; Wallis De Vries \& Raemakers, 2001; Theuerkauf \& Rouys, 2006) for a lasting conservation of insect biodiversity. 
ACKNOWLEDGEMENTS. We are grateful to N. Anthes (Tübingen, Germany), N. Hölzel (Münster, Germany), G. Köhler (Jena, Germany), M. Konvička (České Budějovice, Czech Republic) and two anonymous referees for very helpful comments on an earlier draft of the text. Thanks to I. Edich (Münster, Germany) who translated Russian literature and L. Harris (Münster, Germany) for improving our English.

\section{REFERENCES}

Baur B., Baur H., Roesti C. \& Roesti D. 2006: Die Heuschrecken der Schweiz. Haupt, Bern, Stuttgart, Wien, 351 pp.

Behrens M. \& Fartmann T. 2004: Die Heuschreckengemeinschaften isolierter Schieferkuppen der Medebacher Bucht (Südwestfalen/Nordhessen). Tuexenia 24: 303-327.

Bey-BienKo G.Y. \& MishChENKo L.L. 1951a: Locusts and grasshoppers of the U.S.S.R. and adjacent countries. Vol. I. Keys to the Fauna of the U.S.S.R. 38: 1-400 [translated from Russian by "Israel Program for Scientific Translations", Jerusalem 1964].

Bey-Bienko G.Y. \& MishChenKo L.L. 1951b: Locusts and grasshoppers of the U.S.S.R. and adjacent countries. Vol. II. Keys to the Fauna of the U.S.S.R. 40: 1-291 [translated from Russian by "Israel Program for Scientific Translations", Jerusalem 1964].

BIRKS H.J.B. 2005: Mind the gap: how open were European primeval forests? Trends Ecol. Evol. 20: 154-156.

ChochrJakow S.A. \& Schorin W.P. 2002: Amphibien, Reptilien, Vögel und Säugetiere des Lasowski Sapowednik (Russisch Fernost). Laso, pp. 84.

Dennis P., Young M.R. \& Gordon I.J. 1998: Distribution and abundance of small insects and arachnids in relation to structural heterogeneity of grazed, indigenous grasslands. Ecol. Entomol. 23: 253-264.

Detzel P. 1998a: Phaneroptera falcata (Poda, 1761) - Gemeine Sichelschrecke. In Detzel P. (ed.): Die Heuschrecken BadenWürttembergs. Ulmer, Stuttgart, pp. 213-217.

Detzel P. 1998b: Ruspolia nitidula (Scopoli, 1786) - Große Schiefkopfschrecke. In Detzel P. (ed.): Die Heuschrecken Baden-Württembergs. Ulmer, Stuttgart, pp. 236-241.

Detzel P. 1998c: Parapleurus alliaceus (Germar, 1817) Lauchschrecke. In Detzel P. (ed.): Die Heuschrecken BadenWürttembergs. Ulmer, Stuttgart, pp. 385-390.

Detzel P. 1998d: Oecanthus pellucens (Scopoli, 1763) Weinhähnchen. In Detzel P. (ed.): Die Heuschrecken BadenWürttembergs. Ulmer, Stuttgart, pp. 314-319.

Di Giulio M., Edwards J.P. \& Meister E. 2001: Enhancing insect diversity in agricultural grasslands: the roles of management and landscape structure. J. Appl. Ecol. 38: 310-319.

FARTMANN T. 1997: Biozönologische Untersuchungen zur Heuschreckenfauna auf Magerrasen im Naturpark Märkische Schweiz (Ostbrandenburg). In Mattes H. (ed.): Ökologische Untersuchungen zur Heuschreckenfauna in Brandenburg und Westfalen. Arb. Inst. Landschaftsökol. Westf. Wilhelms-Univ. Münster 3: 1-62.

FARTMANN T. 2004: Die Schmetterlingsgemeinschaften der Halbtrockenrasen-Komplexe des Diemeltales. Biozönologie von Tagfaltern und Widderchen in einer alten Hudelandschaft. Abh. Westf. Mus. Naturkde. 66: 1-256.

FARTMAnN T. 2006: Welche Rolle spielen Störungen für Tagfalter und Widderchen? In Fartmann T. \& Hermann G. (eds): Larvalökologie von Tagfaltern und Widderchen in Mitteleuropa. Abh. Westf. Mus. Naturk. 68: 259-270.

FARTMANN T. \& MATTES H. 1997: Heuschreckenfauna und Grünland - Bewirtschaftungsmaßnahmen und Biotopmanagement.
In Mattes H. (ed.): Ökologische Untersuchungen zur Heuschreckenfauna in Brandenburg und Westfalen. Arb. Inst. Landschaftsökol. Westf. Wilhelms-Univ. Münster 3: 179-188.

Fielding D.J. \& BRUsven M.A. 1992: Food and habitat preferences of Melanoplus sanguinipes and Aulocara elliotti (Orthoptera, Acrididae) on disturbed rangeland in southern Idaho. J. Econ. Entomol. 85: 783-788.

Fielding D.J. \& BRusven M.A. 1993a: Grasshopper (Orthoptera: Acrididae) community composition and ecological disturbance on Southern Idaho rangeland. Environ. Entomol. 22: 71-81.

Fielding D.J. \& BRusven M.A. 1993b: Spatial-analysis of grasshopper density and ecological disturbance on southern Idaho rangeland. Agric. Ecosyst. Environ. 43: 31-47.

Fielding D.J. \& BRUSVEN M.A. 1995: Ecological correlates between rangeland grasshopper (Orthoptera: Acrididae) and plant communities of southern Idaho. Environ. Entomol. 24: $1432-1441$.

Finck P., Klein M., Rieken U. \& SchröDer E. 1998: Schutz und Förderung dynamischer Prozesse in der Landschaft. Schriftenr. Landschaftspfl. Natursch. 56: 1-424.

Gardiner T., Hill J. \& Chesmore D. 2005: Review of the methods frequently used to estimate the abundance of Orthoptera in grassland ecosystems. J. Insect Conserv. 9: 151-173.

Gebeyehu S. \& Samways M.J. 2003: Responses of grasshopper assemblages to long-term grazing management in a semi-arid African savanna. Agric. Ecosyst. Environ. 95: 613-622.

GotTschalk E. 1996: Population vulnerability of the grey bush cricket Platycleis albopunctata (Goeze 1778) (Ensifera: Tettigoniidae). In Settele J., Margules C., Poschold P. \& Henle K. (eds): Species Survival in Fragmented Landscapes. Kluwer Academic Publishers, Dordrecht, Boston, London, pp. 324-328.

GRIME J.P. 1973a: Control of species density in herbaceous vegetation. J. Environ. Manag. 1: 151-167.

Grime J.P. 1973b: Competitive exclusion in herbaceous vegetation. Nature 242: 344-347.

Heller K.-G., Korsunovskaya O., Ragge D.R., Vedenina V., Willemse F., Zhantiev R.D., Frantsevich L. 1998: Check-list of European Orthoptera. Articul. Beih. 7: 1-61.

INGRISCH S. 1979: Untersuchungen zum Einfluß von Temperatur und Feuchtigkeit auf die Embryogenese einiger mitteleuropäischer Laubheuschrecken (Orthoptera: Tettigoniidae). Zool. Beitr. N. F. (Berlin) 25: 343-364.

INGRISCH S. 1980: Zur Feuchte-Präferenz von Feldheuschrecken und ihren Larven (Insecta: Acrididae). Verh. Gesellsch. Ökol. 8: $403-410$.

JOERN A. 1982: Vegetation structure and microhabitat selection in grasshoppers (Orthoptera, Acrididae). Southwest. Nat. 27: 197-209.

JOERN A. 2004: Variation in grasshopper (Acrididae) densities in response to fire frequency and bison grazing in tallgrass prairie. Environ. Entomol. 33: 1617-1625.

JoERn A. 2005: Disturbance by fire frequency and bison grazing modulate grasshopper assemblages in tallgrass prairie. Ecology 86: 861-873.

KEMP W.P. 1992a: Temporal variation in rangeland grasshopper (Orthoptera, Acrididae) communities in the steppe region of Montana, USA. Can. Entomol. 124: 437-450.

KeMP W.P. 1992b: Rangeland grasshopper (Orthoptera, Acrididae) community structure - a working hypothesis. Environ. Entomol. 21: 461-470.

Kemp W.P., Harvey S.J. \& O’Neill K.M. 1990: Patterns of vegetation and grasshopper community composition. Oecologia 83: 299-308. 
KIEChle J. 1998: Pteronemobius heydenii (Fischer, 1853) Sumpfgrille. In Detzel P. (ed.): Die Heuschrecken BadenWürttembergs. Ulmer, Stuttgart, pp. 307-313.

KrivolutsKaya G.O. 1997: Entomofauna of the Kuril Islands: Principal Features and Origin. 1st electronic ed. International Kuril Island Project, http://artedi.fish.washington.edu/ okhotskia/ikip/Results/publications/specialpubs.htm [27/11/ 2007].

Kruess A. \& TscharntKe T. 2002: Grazing intensity and the diversity of grasshoppers, butterflies, and trap-nesting bees and wasps. Conserv. Biol. 16: 1570-1580.

Lockwood J.A. \& SERgeEv M.G. 2000: Comparative biogeography of grasshoppers (Orthoptera: Acrididae) in North America and Siberia: Applications to the conservation of biodiversity. J. Insect. Conserv. 4: 161-172.

Masaki S. \& Oyama N. 1963: Photoperiodic control of growth and wing form in Nemobius yezoensis Shiraki. Kontŷu 31: $16-26$.

MASAKI S. 1996: Geographical variation of life cycle in crickets (Ensifera: Grylloidea). Eur. J. Entomol. 93: 281-302.

Mitchell F.J.G. 2005: How open were European primeval forests? Hypothesis testing using palaeoecological data. J. Ecol. 93: $168-177$.

Newell J. 2004: The Russian Far East. A reference Guide for Conservation and Development. 2nd ed. Daniel \& Daniel, McKinleyville, CA, 466 pp.

PAlMER M.W. 1993: Putting things in even better order: the advantages of canonical correspondence analysis. Ecology 74: $2215-2230$.

Richards O.W. \& WalofF N. 1954: Studies on the biology and population dynamics of British grasshoppers. Anti-Locust Bull. 17: 1-182.

Samways M.J. 1997: Conservation biology of Orthoptera. In Gangwere S.K., Muralirangan M.C. \& Muralirangan M. (eds): The Bionomics of Grasshoppers, Katydids and their Kin. CAB International, Wallingford, pp. 481-496.

SchmidT G.H. 1999: New records of Grylloidea from Africa and the Indian subcontinent (Insecta: Orthopteroidea: Ensifera). $J$. Entomol. Res. Soc. 1: 39-57.

Semenchenko A. 2003: Kievka River Watershed. ed. Wild Salmon Center, http://www.wildsalmoncenter.org/pops/ KievkaRiver.php [15/11/2007].

SERGEEV M.G. 1992: Distribution patterns of Orthoptera in North and Central Asia. J. Orthopt. Res. 1: 14-24.

SERGEev M.G. 1997: Ecogeographical distribution of Orthoptera. In Gangwere S.K., Muralirangan M.C. \& Muralirangan M. (eds): The Bionomics of Grasshoppers, Katydids and their Kin. CAB International, Wallingford, pp. 129-145.

Sergeev M.G. 1998: Conservation of orthopteran biological diversity relative to landscape change in temperate Eurasia. $J$. Insect Conserv. 2: 247-252.

Specht S. 2004: Grasshopper Communities of Flood Plains in the Lazovsky Zapovednik (Primorsky Region, Russia). Diploma Thesis. Institute of Landscape Ecology, University of Münster, Germany.
Stebaev I.V., Muravjeva V.M. \& Sergeev M.G. 1989: Ecological standards of Orthoptera in herbaceous biotopes in the Far East. Entomol. Rev. (Washington) 68(2): 1-10.

Storch D., KonvičKa M., Beneš J., MartinKová J. \& Gaston K.J. 2003: Distribution patterns in butterflies and birds of the Czech Republic: separating effects of habitat and geographical position. J. Biogeogr. 30: 1195-1205.

Storozhenko S.J. 1986: Orthoptera (Saltatoria). In Ler P.A. (ed.): Keys of Insects of the Soviet Far East. Scientific Academy of the USSR, Leningrad, pp. 241-317 [in Russian].

SzÖVÉNYI G. 2002: Qualification of grassland habitats based on their Orthoptera assemblages in the Köszeg Mountains (W-Hungary). Entomol. Exp. Appl. 104: 159-163.

Theuerkauf J. \& Rouys S. 2006: Do Orthoptera need human land use in central Europe? The role of habitat patch size and linear corridors in the Bialowieza Forest, Poland. Biodiv. Cons. 15: 1497-1508.

ter Braak C.J.F. \& Šmilauer P. 2002: CANOCO Reference Manual and CanoDraw for Windows User's Guide: Software for Canocical Community Ordination (Version 4.5). Microcomputer Power, Ithaca.

Torrusio S., Cigliano M.M. \& de Wysiecki M.L. 2002: Grasshopper (Orthoptera: Acridoidea) and plant community relationships in the Argentine pampas. J. Biogeogr. 29: 221-229.

Uvarov B. 1977: Grasshoppers and Locusts. A Handbook of General Acridology. Vol. 2: Behaviour, Ecology, Biogeography, Population Dynamics. Centre for Overseas Pest Research, London, $613 \mathrm{pp}$.

Venevsky S. \& Venevskaia I. 2005: Hierarchical systematic conservation planning at the national level: Identifying national biodiversity hotspots using abiotic factors in Russia. Biol. Cons. 124: 235-251.

van Wingerden W.K.R.E., Musters J.C.M. \& MAaskamp F.I.M. 1991a: The influence of temperature on the duration of egg development in West European grasshoppers (Orthoptera: Acrididae). Oecologia 87: 417-423.

van Wingerden W.K.R.E., Musters J.C.M., Kleukers R.M.J.C., Bongers W. \& van Biezen J.B. 1991b: The influence of cattle grazing intensity on grasshopper abundance (Orthoptera: Acrididae). Proc. Sect. Exp. Appl. Entomol. Netherlands Entomol. Soc. 2: 28-34.

Wallis De Vries M.F. \& Raemakers I. 2001: Does extensive grazing benefit butterflies in coastal dunes? Restor. Ecol. 9: 179-188.

Willott S.J. \& Hassall M. 1998: Life-history responses of British grasshoppers (Orthoptera: Acrididae) to temperature change. Funct. Ecol. 12: 232-241.

Winterholler M. \& Bierwirth G. 2003: Sumpfgrille - Pteronemobius heydenii (Fischer, 1853). In Schlumprecht H. \& Waeber G. (eds.): Heuschrecken in Bayern. Ulmer, Stuttgart, pp. 157-159.

Yan X.D. \& Shugart H.H. 2005: FAREAST: a forest gap model to simulate dynamics and patterns of eastern Eurasian forests. J. Biogeogr. 32: 1641-1658.

December 21, 2007; revised and accepted March 17, 2008 